\title{
Finnish records of discomycetes: Pseudorhizina sphaerospora and Poculum sydowianum
}

\author{
SEPPO HUHTINEN
}

\begin{abstract}
HUHTINEN, S. 1983: Finnish records of discomycetes: Pseudorhizina sphaerospora and Poculum sydowianum. - Karstenia 23: 10-12.

Pseudorhizina sphaerospora (Peck) Pouz. and Poculum sydowianum (Rehm) Dumont are reported for the first time from Finland, each from two localities. Their descriptions are amended. New information is provided on the hyphal characters and the spore structure of $P$. sphaerospora. Further, the red in the stipe base is reported to be strongly fluorescent in UV light. Details are given of the excipular structure of Poculum sydowianum, e.g. the encrustation of the hyphae in the outermost layer, and new features are presented of the ecology. The article is illustrated with a photograph of the former species and microscopic drawings of the latter.
\end{abstract}

Seppo Huhtinen, Department of Biology, University of Turku, SF-20500 Turku, Finland

Pseudorhizina sphaerospora (Peck) Pouz. syn. Gyromitra sphaerospora (Peck) Sacc. - Fig. 1

Finland. Pohjois-Savo: Kuopio, VI.1904 Lönnbohm (TUR 67854). - Perä-Pohjanmaa: Kemi, Pajusaari, grid $27^{\circ} \mathrm{E}$ 7296:386, woody litter, 2.VII.1980 and 3.VII.1981 Fritzén (OULU).

Apothecia stipitate, irregular to roughly globose, $7-10(-23) \mathrm{cm}$ in diam, up to $12 \mathrm{~cm}$ in height; coarsely convoluted, brown, margin free from stipe. Stipe stout, furfuraceous throughout its length, with prominent, longitudinal, sharp-edged ribs continuing to the cap. Base densely tomentous, white with clearly red areas, the reddish tinge also easily observable in dried specimens.

Excipulum of textura intricata, hyphae mostly 5$10 \mu \mathrm{m}$ in diam, septal areas (collars) staining strongly in cotton blue and Congo red; on the underside of the cap the hyphae gradually change to tufted, roundish cells, which cause the furfuraceous appearance under a hand-lens; at the base of the stipe the thick-walled excipular hyphae change gradually to the similar but thinner-walled hyphae forming the white tomentum. Asci up to $300 \mu \mathrm{m}$ long, sporal part $80-100 \mu \mathrm{m}$, spores perfectly globose, $9-10 \mu \mathrm{m}$ in diam, acyanophilous when mature, with one eccentric or many scattered oil globules, which are most easily observable after the removal of the de Bary bubble; towards maturity and also after discharge (taken from stipe base) the spores contain a prominent gas bubble in Melzer's reagent and heated lactophenol; but in heated water, Congo red and $\mathrm{KOH}(5 \%)$ the bubble gradually disappears, as can easily be observed under the microscope. Paraphyses apically brownish, septate, clavate or occasionally capitate, apex $6-12(-25) \mu \mathrm{m}$ in diam.
New to Finland.

The apothecia were growing scattered or in groups of two to four. They were most abundant near a small path. In 1981 the total number of fruit-bodies was ca. 20. The substrate was uniform throughout: mainly small pieces of both coniferous and deciduous wood with occasional remains of bark, mostly in sites without vegetation but in one place with Epilobium angustifolium nearby. The $\mathrm{pH}$ is between 3.9 and 5.5. The area was used for decades as a disposal site for waste from a paper factory (Fritzén, pers. commun.).

In recent times this striking species has been discussed by Harmaja (1969, 1973, 1974), Ryman (1978) and Gilsenius (1981). Gilsenius' material was reported to have a greyish hymenium. Harmaja created a new family, Pseudorhizinaceae, to accommodate the genus Pseudorhizina Jač. It embraces two species, $P$. sphaerospora and $P$. californica (Phill.) Harmaja. Among the characters distinguishing it from Helvellaceae and/or Rhizinaceae Harmaja stressed the simple excipular structure, the lack of a cyanophilous perispore in the mature spores and the thick-walled excipular hyphae (Harmaja 1974).

In the present material the walls of the excipular hyphae are generally sligthly thickened, the hyphae with the thickest walls being observed at the base of the stipe. However, this feature can be observed also in the genus Helvella. The septal collars described by Harmaja (1973) occur frequently on the hyphae and also stain deeply in Congo red. However, I failed to observe $(\times 1500)$ the cyanophilous perisporium in young spores, which according to Harmaja (1974) has a maximum thickness of $0.2-0.3 \mu \mathrm{m}$.

My observations on the presence of de Bary bubbles in dried material turned out to be somewhat dif- 
ferent from those reported by Harmaja (1973). He stated that the bubbles are present in water and $5 \%$ $\mathrm{KOH}$ as well. I found that the bubble disappeared in these mountants after gentle heating. The same thing happened in Congo red $\left(\mathrm{NH}_{3} \mathrm{OH}\right)$. Although the bubbles are persistent in lactophenol and Melzer's reagent, they can be removed by pretreatment with heated water. This effect of heated water can be observed in various other genera, too, e.g. Otidea and Pulvinula.

Specimens with a basally violaceous stipe (Pouzar 1961) have been called Pseudorhizina sphaerospora (Peck) Pouz. forma gabretae (Kav.) Pouz. The colour on the stipe is described as intensely violet-pinkish when well developed. When not so deep, it is seen as a violet tinge. This handsome form is restricted to Czechoslovakia. In the present specimens the basal areas have reddish to reddish-brown colour - a regular feature in $P$. shaerospora (cf. Harmaja 1973). The coloured areas contrast strongly with the tomentum of the uncoloured parts under UV light (254 and 366 $\mathrm{nm})$ : the reddish patches have a deep violet fluorescence while the tomentum otherwise appears white.

This morphologically and phenologically prominent species is apparently rare in northern Europe. Eckblad (1968) reports one collection from Norway and Ryman (1978) and Gilsenius (1981) together four from Sweden. For Finland the following herbaria were consulted: $\mathrm{H}, \mathrm{KUO}$, OULU and TUR.

\section{Poculum sydowianum (Rehm) Dumont - Fig. 2}

Finland. Varsinais-Suomi: Turku, Katariinanlaakso, grid 27 ${ }^{\circ}$ E 6709:239, on leaves of Quercus robur, 13.IX.1968 Kankainen (TUR 61293); Turku, Ruissalo, grid $27^{\circ} \mathrm{E} 671: 23$, on leaves of Quercus robur, 14.IX.1980 Huhtinen \& Huhtinen (TUR 67582).

Apothecia stipitate, solitary or rarely $2-3$ on the same leaf, cylindrical with a small pore when young, then expanding; disc $1.0-1.5 \mathrm{~mm}$ and up to $2.5 \mathrm{~mm}$ in diam, clearly marginate with short, pointed, dark brown teeth, lighter than the other parts; flanks yellow-brown and under hand-lens $(\times 10)$ with darker, longitudinal striae, which continue to the stipe. Stipe mostly firm, $1.0 \times 0.3 \mathrm{~mm}$, yellow-brown, base darker.

In section showing five excipular layers. Subhymenium ca. $20 \mu \mathrm{m}$ thick, composed of tightly packed brown textura intricata. Medullary excipulum of paler and loosely interwoven t. intricata, hyphae smooth. Innermost layer of ectal excipulum composed of $\mathrm{t}$. porrecta, ca. $30 \mu \mathrm{m}$ thick, darker than the preceding layer, hyphae with minute or up to $0.5 \mu \mathrm{m}$ high external, brown granules. Outside the t. porrecta is a gelatinized layer, made of narrow hyphae (textura oblita), ca $40 \mu \mathrm{m}$ thick.

The thin outermost layer of the ectal excipulum is formed by variable hyphae running parallel to the

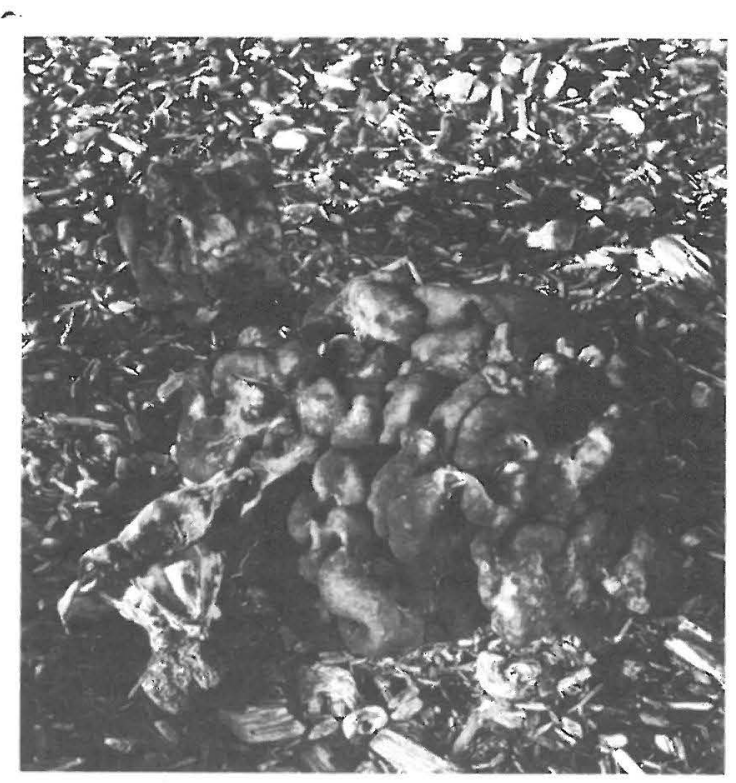

Fig. 1. Pseudorhizina sphaerospora (1981 Fritzén, OULU). The diameter of the largest apothecium is $23 \mathrm{~cm}$. - Photo: Nils Fritzén.

surface. These hyphae are brown, minutely to coarsely granulated, the most heavily encrusted causing the striated appearance under a hand-lens. Asci 110-120 $\times 9-10 \mu \mathrm{m}$ long, $\mathrm{I}+$. Spores uniseriate, obovoid -reniform, $11.5-12.5 \times 5.0-6.0 \mu \mathrm{m}$, aseptate, usually with only one large, irregular oil globule or with a small accessory globule (observed in cotton blue in lactophenol ). Paraphyses subclavate, $2 \mu \mathrm{m}$ in diam.

New to Finland.

According to White (1941) the closely related Poculum petiolorum (Rob. in Desmaz.) Dumont \& Korf has an ectal excipulum made up of two layers and lacking the innermost layer of textura porrecta. The spores at the apex of the ascus are biseriate, larger $(14-17 \times 4.5-5.5 \mu \mathrm{m})$ and become $2-3$-septate at late maturity. Both the species are figured in Breitenbach \& Kränzlin (1981).

The gelatinization in the ectal excipulum is the main criterium for placing this species in the genus Poculum. Poculum sepiaceum (Thind, Cash \& P. Singh) Dumont differs from present species in having outer ectal excipulum composed of textura prismatica (Dumont 1976).

The description of $P$. sydowianum by White (1941) fits well with the present material. However, he did not report that the non-gelatinized part of the ectal excipulum was composed of granulated hyphae. The encrustation is constantly present and very prominent in some of the hyphae.

I first identified this species in 1978 from material collected in Turku, Ruissalo, from two study areas 


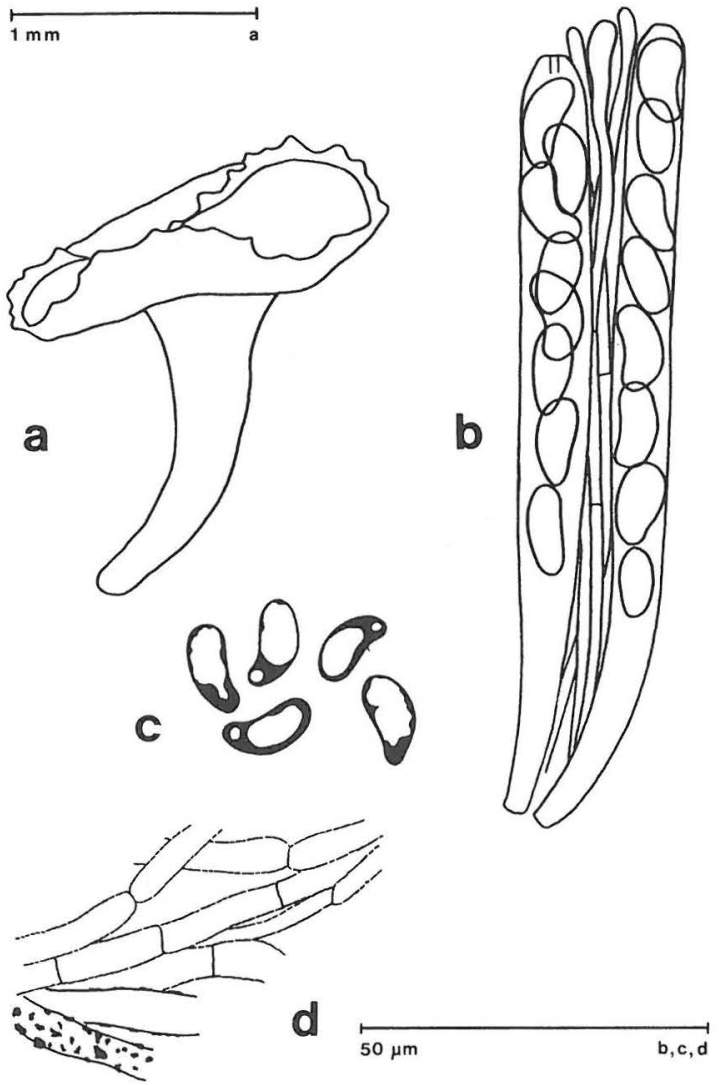

Fig. 2. Poculum sydowianum. a) apothecium, b) asci and paraphyses (in Melzer's reagent), c) spores (in cotton blue), d) hyphae from the surface showing variation in encrustation. Camera lucida drawings.
(Ohenoja 1980). Later this material was lost. In 1980 ca. 60 apothecia were observed. They were growing almost exclusively near the bases of oak-leaf petioles. This might be because these parts of the petioles are often sticking out of the thick deciduous litter on the forest floor, thus offering a suitable microhabitat.

Poculum sydowianum should also be sought around planted oak trees outside the hemiboreal zone, i.e. the natural range of the oak.

Acknowledgement. I am indebted to Nils Fritzén, M. Sc., for accurate field notes and photographs.

\section{References}

Breitenbach, J. \& Kränzlin, F. 1981: Pilze der Schweiz 1. Ascomyceten. - 313 pp. Luzern.

Dumont, K.P. 1976: Sclerotiniaceae 12. On some selected species from India. - Mycologia 68: 842-873.

Eckblad, F.-E. 1968: The genera of the operculate Discomycetes. A re-evaluation of their taxonomy, phylogeny and nomenclature. - Nytt Mag. Bot. 15: 1-191.

Gilsenius, B. 1981: Pseudorhizina sphaerospora (Peck) Pouz. funnen i Jämtland. - Göteborgs Svampklubb, Årsskrift 1981: 57-59.

Harmaja, H. 1969: A wider and more natural concept of the genus Gyromitra Fr. - Karstenia 9: 9-12.

- 1973: Amendments of the limits of the genera Gyromitra and Pseudorhizina, with the description of a new species Gyromitra montana. - Karstenia 13: 48-58.

- 1974: Two new families of the Pezizales: Karstenellaceae and Pseudorhizinaceae. - Karstenia 14: 109-112.

Ohenoja, E. 1980: Sienisatotutkimus vv. 1976-78. - EKTsarja 548: 1-41. University of Helsinki.

Pouzar, Z. 1961: Systematická hodnota ucháčovce šumavského - Helvellella gabretae (Kavina) Pouz. et Svr. The taxonomical value of Helvellella gabretae (Kavina) Pouz. et Svr. - Ceská Mykol. 15: 42-45.

Ryman, S. 1979: Svenska vår- och sommarsvampar inom Pezizales. Swedish Pezizales of spring and early summer. - Svensk Bot. Tidskr. 72: 327-339.

White, W.L. 1941: A monograph of the genus Rutstroemia (Discomycetes). - Lloydia 4: 153-240. 